DOI 10.37882/2500-3682.2020.07.12

\title{
НА «ПУТИ К ЯЗЫКУ» (М. ХАЙДЕГГЕР): АНТИ-ЛИНГВИСТИКА
}

\section{«THE PATH TO LANGUAGE» \\ (M. HEIDEGGER): ANTI-LINGUISTICS}

\section{Kostetckii}

Summary: The article is based on the well-known thesis that the language cannot be understood from the language. However, the measures taken to understand language through semiotics and social relations must be recognized as completely insufficient. As a starting point for the philosophy of language to go beyond language, we should accept the fact of excessive complexity of language for the purposes of interpersonal communication, especially in comparison with the fact of excessive human sexuality. Heidegger's calls to understand language through poetry, and to see in poetry the intentionality of the gods, should be developed into an ontology of the gods, in relation to which the ontology of language will be secondary. Ethnographic materials on trance rituals of primitive culture and modern research on «altered states of consciousness» clearly contribute to the latest research on the «path to language».

Keywords: language, theory of meaning, Aristotle, ontology of language, ontology of look, prescription knowledge, subject, sacred, shamanism, poetry, Heidegger. «...мир всевидящ...» Ж.Лакан

«жизнь вселенной - это вечный тысячеустный разговор»

Новалис

$\Phi$ илософия языка, казалось бы, не может угрожать каким-либо образом философии культуры, особенно в её привычном гуманитарно-гуманистическом понимании, поскольку культура, вроде бы, и начинается с языка. Но из этого в общем-то верного факта не следует, что язык можно понять через культуру. Между тем, за последние два столетия сложилась «научная» практика понимания языка через культуру и понимания культуры через язык и языки. В этом замкнутом круге всё становится самосогласованным по принципу «рука руку моет». Симуляция научного понимания языка и понимания культуры осуществляется благодаря понятию «семиотика», посредством которого язык интерпретируется как одна из знаковых систем, а культура, в свою очередь, как множество «языков», множество знаков и «символических форм».

Второй координатой той плоскости, на которой теоретезируются язык и культура, является «система социальных отношений» («коммуникация»), в рамках кото-
Костечкий Виктор Валентинович

Д.ф.н., профрессор, Санкт-Петербургский государственный академический Институт живописи, скульптуры и архитектуры имени И.Е. Репина при Российской академии художеств, kostavictor@yandex.ru

Аннотация: В основу статьи положен известный тезис о том, что язык невозможно понять из языка. Однако, предпринимаемые меры понимания языка через семиотику и социальные отношения надо признать совершенно недостаточными. В качестве исходного начала выхода философии языка за пределы языка следует принять факт избыточной сложности языка для целей межчеловеческого общения, особенно в сопоставлении с фактом избыточной сексуальности человека. Хайдеггеровские призывы понимать язык через поэзию, а в поэзии усматривать интенциональность богов, следует развить до онтологии богов, по отношению к которой онтология языка окажется вторичной. Этнографические материалы по трансовым ритуалам первобытной культуры и современные исследования «измененных состояний сознания» явно способствуют новейшим исследованиям на «пути к языку».

Ключевые слова: язык, теория значения, Аристотель, онтология языка, онтология взгляда, рецептурное знание, субъект, сакральное, шаманизм, поэзия, Хайдеггер.

рой и появляются знаковые системы семиотики. Теории семиотики и коммуникации оказываются настолько координированными между собой, что любая попытка понять язык и культуру приводит всегда к тому, что все дороги теоретического осмысления ведут либо через семиотику к социальным отношениям, либо через социальные отношения к семиотике. И других вариантов, вроде бы, нет, а, возможно, и быть не может.

Попыткой, причем достаточно робкой и непоследовательной, можно считать выдвинутый М. Хайдеггером лозунг «язык - дом бытия», причем этот лозунг то признавался автором за «фундаментальную онтологию», то переводился в метафору. В рамках этих колебаний, соответственно, появляется выражение «путь к языку», о котором М. Хайдеггер утверждал, что «...путь к языку как языку длиннейший из всех, какие можно помыслить» [Хайдеггер 1993, 259]. Во всяком случае, можно с уверенностью утверждать, что великий немецкий мыслитель XX века не видел направления и изгибов этого «пути к языку», но точно знал, что столбовая дорога к нему заказана, на которой - как в то время, так и до сих пор, - бал правят лингвистика, семиотика, социология, психология и весь набор социально-гуманитарных наук с «междисциплинарным подходом» во главе. М. Хайдеггера не устраивала семиотическая методология языка, о чем он 
прямо писал: «...язык...никогда и не удастся сущностно осмыслить ни из его знаковости, ни, пожалуй, даже из его семантики» [Хайдеггер 1993, 199]. Осторожно сомнения в знаковой-де природе языка высказывал еще В. Гумбольдт: «...сравнение (языков - В.К.) привносит своеобразный смысл, отличающий язык от простых условных знаков, хотя в обиходе и проявляется склонность к такому отождествлению...Но, что еще важнее, такое изучение приучает дух видеть в словах нечто большее, нежели случайные звуки и условные знаки» [Гумбольдт 1985, 365-366].

Я попытаюсь в своей статье придать определенность тому, что В. Гумбольдт обозначил как «нечто большее» В языке, то есть не случайное и не условное, в направлении которого и держал свой «путь к языку» М. Хайдеггер.

Надо заметить, что научное сообщество, провозглашая о том, что «в науке нет широкой столбовой дороги», очень не любит, когда с неё сворачивают на иные пути. И «путь к языку» не является исключением, поскольку столбовая дорога философии языка давно проложена: во-первых, знаки-символы, во-вторых, отношения между людьми. Но, возможно, что «путь к языку» и начинается, и проложен не в этой, «профанной», реальности. В наших гуманитарных науках «сакральное» имеет значение чего-то этнографического или, в лучшем случае, трансцендентально-экзистенциального. М. Хайдеггер не очень владел этнографическим материалом (и это, по моему мнению, отрицательно сказалось на его философии), а от литературного экзистенциализма держался на расстоянии. Поиски своего «пути к языку» вне этнографии и экзистенциального психологизма вывели М. Хайдеггера на иной путь - на поэзию в её сакральном (и не субъективном) измерении. О том, что настоящая лирическая поэзия не субъективна, писал ещё Ф. Ницше. Как только в лирике появляется дух вместо чувственности, так индивидуализм и субъективность уходят на второй план. Соответственно, М. Хайдеггер на пути к языку обнаруживает онтологический мотив поэзии, открывая тем самым иное направление в философии языка, нежели семиотика и социальность, - поэзию в её внесубъективной духовности. Координата поэзии ортогональна плоскости семиотики и социальности, это совсем другая координата теоретического понимания языка. Под поэзией немецкий философ понимает, конечно, не стихотворчество, а форму вдохновенного пророчества, хотя и абстрактного. Таков у него Гёльдерин - «поэт поэтов». Как писал М. Хайдеггер при анализе поэзии Гёльдерлина, «поэзия есть праязык всякого исторического народа. Таким образом, наоборот, сущность языка должна пониматься из сущности поэзии» [Хайдеггер 2003, 85].

Довольно любопытно наблюдать над тем, с каким сарказмом филологи способны воспринимать мысли философа о языке: «Понятно, - пишет Н.Б. Мечковская,
- что хайдеггеровский Язык «с большой буквы» - это, в сущности, уже не язык, а поэтический символ «всего высокого и прекрасного», может быть, и лестный для «традиционного языка с его грамматикой», но и уводящий проблему «язык и познание» в область поэзии и мифологии» [Мечковская 1988, 306]. Для филолога, автора монографии «Язык и религия», никаких философских проблем осмысления сущности языка и религии не существует, поскольку есть уже раз и навсегда найденная точка зрения: «С точки зрения семиотики (науки о знаках) - пишет Мечковская - язык и религия - это две самобытные знаковые системы, обладающие своим содержанием и своим способом передачи этого содержания» [Мечковская 1988, 3].

В том, что в языке и религии есть знаки, никто и не сомневается. Но язык и религия - это не системы знаков, а нечто много большее. Возможно, имеющее отношение к духовности, к духу как иной реальности, трансцендентальной по отношению к собственно человеческим инициативам. Язык и религия в своих знаковых формах (текстах, шифрах) уже, собственно, и не язык и не религия. Как замечал Аристотель, «рука, отделенная от тела, лишь по названию рука». Точно так же язык можно закодировать в звуки, письмена, превратить в средство общения и мышления, в речевую деятельность, но это будет язык на потребу, отделённый от языка как такового. Например, европейская музыка с её набором инструментов, динамических оттенков, системой консонансов не тождественна Музыке (как таковой), поскольку музыка не сводится к музыкальному звуку и акустике. Язык можно сравнивать с музыкой, можно сравнивать с поэзий, но нельзя непосредственно связывать со звуком и словом; язык как таковой не акустичен, не графичен и даже не сигнален.

Язык есть настолько странная реальность, что возникает искушение вообще отказать языку в реальности, то есть представить язык как искусственное изобретение типа географической карты, придуманным учителями для обучения «иностранному языку». С этой точки зрения, язык - это «контурная карта» говорения, слушания, общения; тогда в реальности нет «языков», реальны только знаки и общение.

Другая точка зрения состоит в том, что знаки и общение потому и существуют, что существует язык, который может иметь различное материальное обеспечение. Не случайно Ф.де Соссюр заявлял о том, что французский язык - это латынь, но в другое время и в другом месте, равно как латынь - это санскрит в другое время и в другом месте. Соответственно, путь к языку идет мимо французского и латыни, латыни и санскрита, вообще мимо «сравнительной грамматики». 
Если задаться вопросом о том, куда ведет путь к языку, то ответ на него возможен, но возникает проблема в подборе слов. Язык связан с «знанием», «узнаванием», «пониманием», «прозорливостью», но, возможно, наиболее подходящим термином будет старинное слово «весть», «вести». В этом слове сокрыто субъектное начало знания, податель вести. Любое слово в речи несёт субъектность вести. Не случайно в языке вещь всегда не только объект, но и субъект: время бежит, гроза утихла, - и дело отнюдь не сводится к антропоморфизму. Время - это не часы, но активный субъект многих ситуаций, отчего Ф. Соссюр в своей лингвистике писал Время (с заглавной буквы) как обозначение персоны, П. Бомарше шутил о том, что «время - честный человек», а В. Даль приводил редкую поговорку «дураку что ни время, то и пора». Как бы то ни было, но в слове «время» присутствует субъектное начало, нравится это физикам или нет. Слово с присутствием «субъектного начала» есть «весть». Анонимный вестник в вести слова как раз и представляет особый философский интерес.

Вестник всегда субъект. Субъект реален в конкретной ситуации, в которой он существует как агент этой ситуации. По отношению к человеку субъект (обстоятельств) может демонстрировать себя как вещами (натурой), так и словами в речевом исполнении. Соответственно, вещь для «субъекта обстоятельств» (таким субъектом и было Время у Ф. Соссюра) ровно такой же знак, как и слово для её обозначения в человеческих языках. Приведу простой пример под видом «теории значения». Исходным предметным значением (референтом) слова «волк» является не хищник, а множество историй («вестей») об опасности, связанной с этим хищником. В этих историях «волк» фигурирует в качестве субъекта (даже если этого самого волка никто в глаза не видел). Когда в зоопарке укажут на волка, то видимый хищник презентует собой те же самые «страшные истории», выступает по отношению к ним точно таким же знаком, как и произносимое ранее слово. Дихотомия «вещь-имя», при которой вещь становится «объектом», а слово «знаком», возникает за счет того, что упускается из виду исходная ситуация с множеством рассказов о ней. Между тем, вещь принимает свой иконический образ далеко не сразу; так, волка надо еще научиться (рассказами) отличать от лисы, шакала, росомахи, рыси, медведя. Лишь в итоге образ вещи закрепляется в форме зримой эмблемы, а слово становится фонетическим знаком этой иконической эмблемы (а не «самой вещи»). Когда со временем фонетика слова меняется, а эмблема остается неизменной, возникает бытовое представление о «вещи-самой-по-себе», о вещи-объекте; соответственно, слово предстает как условный знак, этикетка.

Представленная в данном примере «теория значения» впервыепоявляется в философии Аристотеля, в которой она играет едва ли не главную методологическую роль. В известном аристотелевском примере «человек
- сказывается о Сократе» отнюдь не утверждается, что «Сократ есть человек» (так стали говорить стоики уже после смерти Аристотеля). В философии стоиков Сократ рассматривается как один человек из многих людей, количественно. В аристотелевской философии «человек» - это множество историй о людях, объединенных одним словом (наподобие заглавия рассказа); точно так же «Сократ» - это не тело Сократа, а множество историй о нем. Поскольку сведения о людях и Сократе во многом совпадают между собой, постольку возможно утверждение «человек-сказывается о Сократе». Причем, уместно задать вопрос: кем или чем одно «сказывается» о другом? У Аристотеля нет автора этого сказителя, поскольку «сказываемость» обусловлена множеством тех объективных обстоятельств, которые явились поводом для всех рассказов «О человеке», «О Сократе». У Аристотеля слово образовано рассказами, а не рассказ состоит из слов. В быту все рассказы, положенные в основание слова (как «заглавия»), сокращаются до «имеется в виду», образуя тем самым «смысл». В «смысле» слова смысла не больше того, что представлен в рассказах, озаглавленных соответствующим словом. Что касается Аристотеля, то его «смыслы» слов не занимают вовсе; ему интересны истории о том, кто и как употребляет слова и в каких именно ситуациях. Поэтому «исторические введения», которыми пронизаны все тексты Аристотеля, это, собственно, не «обзор мнений» наподобие доксографии, а материал для «теории значения», на основе которой и строится дальнейший философский текст.

Свою «теорию значения» Аристотель менее всего связывает со словами и знаками вещей. Значение, обозначенное знаками, уходит даже не «к самим вещам» (Э. Гуссерль), а к тем ситуациям-обстоятельствам, которые вызвали существование «самих вещей». Вещь в контексте обстоятельств её появления на свет Аристотель будет называть сконструированным им термином «энтелехия». Вещь-энтелехия обязательно пребывает в напряженном диалоге с обстоятельствами, её породившими (обстоятельства «тестируют» вещь; вещь «несется к своей цели», хотя и поставленной не самой вещью). Диалог ведется по каналам «категорий» (еще одно слово, придуманное Аристотелем). Именно этот диалог энтелехий по каналам категорий образует Язык «сказываемого» (в смысле, близком М. Хайдеггеру) и проявляется как «энергия» в теории языка В. Гумбольдта. После Аристотеля стоики интерпретировали «энтелехию» в качестве «тоноса» (напряженное бытие), а римские стоики перевели греческий «тонос» как «интенция» (в том же значении). В арабо-латинском средневековье термины «интенция», «интенциональность» пользовались большой популярностью в качестве обозначения одухотворенности бытия (это именно то «бытие», с которым работал всю жизнь М. Хайдеггер, начиная с Dasain - то есть после диссертации 1915 года о 


\section{Дунсе Скотте).}

Язык, в отличие от множества слов, то есть как способ представления субъектности бытия (субъектности обстоятельств), существует не для человека и вне человека; человек открывает для себя язык как он открывает для себя полезные ископаемые. То, что получается из полезных ископаемых, совсем не похоже на сами полезные ископаемые. Точно так же и с человеческими языками в их многообразии и своеобразии: они не похожи на язык как таковой, но они существует на его основе, они «из него сделаны». О «нечеловеческом» в языке писал еще В. Гумбольдт: «Язык коренится в человеке, но всё же не мог быть им выдуман. Язык - нечто большее, нежели инстинкт интеллекта...» [Гумбольдт 1985, 365]. Люди не создают язык, как не создают они «законы природы»они его для себя открывают, оформляя через поэзию. Собственно, и про поэзию можно сказать, что поэзия всего лишь способ открытия языка. Язык открывается человечеству в поэзии, а потом используется где угодно, поскольку в реальности все обстоятельства субъектны. В этом смысле во всём есть язык и всё, что есть в мире, есть нечто типа поэзии, для которой в природе «всё разговор». При поэтическом восприятии реальности «... горы смотрят на меня, $Я$ смотрю на горы, $\backslash И$ нам это не надоедает» (из китайской поэзии). Или у А. Толстого: «И слышу я, как разговор везде немолчный раздается...». Поэтическим признаниям на этот счет нет числа. При поэтическом восприятии реальности субъектность вещей не привносится антропоморфизмом или метафорами и аналогиями, а лишь приоткрывается, узнается. Как писал Н.А. Бердяев: «Некоторый антропоморфизм должен быть утверждаем не стыдливо и робко, а сознательно и смело» [Бердяев 1990, 42]. Поэтому не так уж далек от истины Новалис, утверждая, что чем поэтичнее, тем ближе к истине.

Поэтическое восприятие природы легко обвинять в антропоморфизме, в анимизме, в аниматизме, в гилозоизме, в преувеличении, в образности, в метафоричности; однако, в основе собственно поэтического восприятия заложено личностное восприятие субъектности всего сущего, всего того, что может быть «объектом» мысли, чувства, фантазии. В нашей философской литературе много писано о единстве субъекта и объекта, их «принципиальной координации» или первичности того или другого. Однако, главным в этом вопросе является то, что субъекта не надо связывать с человеком, с сознанием, с органами чувств. Как утверждал М. Хайдеггер, «метафизическое значение понятия субъекта не имеет ближайшим образом никакого подчеркнутого отношения к человеку и тем более к Я» [Хайдеггер 1993, 48]. С другой стороны, хайдеггеровская позиция означает, что свое «я» есть у каждой вещи, так что человек в отношении субъектности не является уникумом. Человека и вещь как субъектов объединяет то, что называется «видени- ем», причем, безотносительно телесности. Так, например, во сне мы видим не глазами, и слышим не ушами, и говорим не органами речи. Во сне мы остаемся субъектами, но феноменально, вне своей телесной организации. Точно также любой субъект при любой телесной организации (электрон, камень, планета, звезда) «видит» свое окружение, видит трансцендентально. Трансцендентализм в этом случае означает видение вещами друг друга, а если речь идет об отношении человека к вещам, то признание того факта, что вещи видят, как человек их видит. В качестве пояснения можно сослаться на опыт повседневной жизни: женщины всегда видят, как мужчины на них смотрят (причем видят не глазами, а неведомым образом перехватывая взгляд). Язык и существует как сущее именно в реальности трансцендентального видения, это его родная стихия. По этому поводу есть остроумное замечание М. Мерло-Понти: «Послушаем, что говорит Мариво: «Я и не думал называть вас кокеткой. - Это было сказано до того, как об этом подумалось» [Мерло-Понти 2001, 24] Это «сказанное» (неизвестно каким образом) есть та самая реальность, которая занимала Аристотеля (начиная с «Категорий») и у которой после Аристотеля много других названий, таких, как «Geist» Гегеля или «Dasain» Хайдеггера.

Субъектность вещей, фиксируемая в поэзии, означает, что вещи не только «ведут разговор», но видят друг друга, обмениваются взглядами, приемлют или не приемлют друг друга - феноменология этого «общения» существует, но, естественно, вне привычной человеку телесности. Для того, чтобы видеть, необязательно иметь глаза; видеть - это феномен и атрибут субъектности. Об этом догадывался еще Цицерон, ориентируясь на Аристотеля: «А ведь мы воспринимаем видимое не глазами...видит и слышит именно душа, а не части тела, которые служат ей как бы окошками, но которыми ничего нельзя чувствовать без присутствия и участия ума» [Цицерон 1975, 223]. Умопостигаемость видения, трансцендентальность его, имеет свою странную физику, на которой более всех настаивал М. Мерло-Понти: «Видение - это не один из модусов мышления или наличного бытия «для себя»: это данная мне способность быть вне самого себя...и моё «я» завершается и замыкается на себе только посредством этого выхода во вне» [МерлоПонти 1992, 51]. Теоретическая позиция М. Мерло-Понти выводит видение из сферы разговорного языка на уровень, представленный в этнографии шаманизмом, - с последующим осмыслением его посредством концепта «измененных состояний сознания».

В философском понимании субъект представляет собой понятие абстрактное и всеобщее. Я попытаюсь конкретизируется это понятие несколькими признаками, «атрибутами» (подобную конкретизацию можно, кстати, найти и у М. Хайдеггера, процеживая его многословие). Во-первых, субъект - это то, что видит свое окружение, 
имеет свою точку зрения (Blickstand) на окружающее. Во-вторых, субъект всегда предпринимает попытки господствовать над всем, что видит. В-третьих, субъект капризно волит быть любимым всеми, кто видит его (онтологическую «капризность» субъекта одним из первых подметил Ф.М. Достоевский). Когда говорят о том, что любовь правит миром, то в этом есть онтологическая правда. Но точно так можно говорить о том, что воля правит миром (на чем, как известно, настаивал А. Шопенгауэр). Три атрибута субъекта играют в организации миропорядка роль принципа разделения властей. Так, если господство становится чрезмерным, перестают любить. Если любовь переливается через край, то умаляется воля к власти. Если видение становится всевидящим, то меркнет любовь и атрофируется воля. Если в мире и есть некое саморегулирование, то осуществляется оно исключительно субъектными отношениями всего со всем. В отношении субъекта всё сущее едино, от творца до творений. Выражаясь старинным философским языком, можно сказать, что единство мира в его субъектности, а не в чем-либо другом типа материи, бога, абсолюта, субстанции.

Субъектность вещей обладает одной странной особенностью, имеющей для понимания языка принципиальное значение: она может отделяться от самой вещи, превращаясь-перемещаясь в слово, в язык, в картину. Типичным примером может служить такое странное социальное явление благополучной Европы, как «секс по телефону»: вся феноменология секса оказывается в разговоре. Точно так же при вуайеризме феноменология секса оказывается в подглядывании, так что на долю телесности остается нечто подобное целованию деревянными куклами. В той же логике могли бы, например, существовать «драка по телефону» или «ужин по телефону». Это может показаться забавным, но феномен европейской классической музыки и жанры приключенческого романа существуют точно таким же «телефонным способом» - «разговором». Меломаны и книголюбы смещаются из одной реальности в другую, порой выпадая собственным субъектом из реальности вещей. Реальность способна двоиться, позволяя уходить в язык и появляться из языка. Подобное возможно только благодаря тому, что язык как таковой представляет собой не систему знаков, а систему межсубъектных отношений вещей. В поэзии А. Толстого есть такие строки:

«И вещим сердием понял я,

Что всё, рожденное от слова,

Лучи любви кругом лия,

К нему вернуться жаждет снова».

Вещи вещают о себе, так появляется феноменология бытия отдельно от телесности - «немолчный разговор» (А. Толстой), «сказываемое» Аристотеля. Поэты, прислушиваясь к «сказываемому», начинают вдруг бормотать, завывать, шептать, шевелить губами в поисках фонем - из чего рано или поздно складывается изначальная «речь». Наглядным примером может служить замечательный поэтический опыт в «Розе мира» Д. Андреева.

Поэтический шаманизм сам по себе вряд ли привел бы к формированию членораздельной речи, если бы в нем не было того, что называется «вестями», «знанием». Нечленораздельная речь «поэтов» сопровождалась вполне содержательными видениями, как это имеет место, к слову сказать, в европейской классической музыке с её прочувственными образами «бури и натиска». Экстатическая экзальтация шаманствующих поэтов (не без влияния растительных галлюциногенов) позволяла вклиниться в разговор вещей между собой, например, организма и ландшафта, что приводило к так называемому «рецептурному знанию», которое в культуре приняло форму сначала знахарства, потом медицины. Рецептурное знание в цивилизации оказывается доступным немногим (жрецам, гениям, пророкам, энтузиастам); между тем все исходные знания цивилизации в области медицины, строительства, математики, геологии, доместикации растений и животных получены рецептурным путем, то есть поэтическим вдохновением жрецов-энтузиастов в их трансовых ритуалах.

Возможности шамано-жреческого познания распространялись не только на технологии медицины, математики, металлургии, транспорта, строительства, сельского хозяйства, но и на ту область, которую стали связывать с религией. Религия - это, собственно, та область реальности, где субъектность представлена в отдаленности от вещей, в персоналистичном виде. Так появляются «этот» мир с людьми и «тот» мир» с ангелами, архангелами, чистой и нечистой силой. В философии языка, в филологии и лингвистике про «двоемирие» не вспоминают, стремясь ограничиться этим миром, в котором далее сравнительного языкознания, семиотики и психологии социальных отношений на «пути к языку» продвинуться невозможно.

Но язык - явление не этой реальности, то есть вещной. Человеческие языки, с которыми имеют дело лингвисты, являются поздним продуктом открытия языка и преобразования его под текущие нужды. Если воспользоваться аналогией, то можно говорить об открытии огня (дар Прометея), и отдельно о способах его применения (обогрев, освещение, теплотехника - от кулинарии до металлургии). В продолжение аналогии с огнем можно сделать существенное уточнение: не человек открыл для себя язык, а человеку открыли язык в качестве подарка от каких-либо «прометеев». И не факт, что подарок преподнесен бескорыстно. Не случайно М. Хайдеггер обращает внимание на поэтическое высказывание Гёльдерлина: «...и потому опаснейшее благо - язык дан человеку, чтобы он, творя и разрушая, ...показал, что он есть такое...» [Хайдеггер 2003, 69] 
В свое время И. Кант, как известно, обнаружил ограниченность человеческого разума. За приделы дозволенного познания человеку выйти не дано. А всё то, что доступно познанию, оказывается в превращенном виде, наподобие сказок детям об их появлении на свет. Философия истории дополняет кантовский агностицизм малоутешительными заявлениями о том, что человеческая история - не арена счастья, что человек - игрушка, что лучшее для человека - вообще не родиться. В философии языка пессимистичные выводы философии истории почему-то не принимаются во внимание, а зря. Языки человеческие принимают самое активное участие во всей трагедии человеческой истории, при этом люди далеко не являются хозяевами своего языка, ни один народ не является автором того языка, на котором он говорит. Максимум того, что доступно человеку в отношении языка - это перейти на язык другого народа. Человек, рождаясь, при всей своей активности остается ведомым (языком). Если игнорировать религию, то язык начинает казаться средством общения и сознания, системой условных знаков, системой рефлексов. Если не игнорировать религию с её тысячелетним опытом, то язык получит другое концептуальное содержание. А именно: человеческие языки выстроены на границе «двоемирия»; это место встречи персонажей этой и той реальностей; с одной стороны, людей и, с другой стороны, персонажей трасцендентной реальности, - как бы их не называли: духи, боги, демоны, пенаты, архангелы, шайтаны, гении, бесы. Так что за трагедийные события человеческой истории ответственность несут не только люди. Историкам и культурологам никогда не объяснить «человеческим фактором» бесчеловечные ужасы мировых войн с участием самых культурных наций, забывая сакраментальное «бес попутал».

Существует такой детский вопрос: где живут боги? В философии на него можно дать, допустим, такой ответ: где постоянно живут боги - конечно, неизвестно, но иногда они живут в языке. У М. Хайдеггера было выражение «язык - дом бытия»; в этом философско-поэтическом высказывании есть та правда, в которой образ дома верен буквально: язык - это дом, только не абстрактного «бытия», а реальных персонажей из трансцендентной реальности. Кстати, дом - это не здание, а то место уютного бытия, где, как писал В. Высоцкий, «Пусть ночью, днем, Всегда твой дом. $И$ здесь не смотрят на тебя с укором». Человеческий язык сформирован под уютный храм для общения людей и богов. Пожалуй, метафора «храма» как места встречи людей и богов более всего выражает суть языка.

Человек в родном языке является всего лишь «прихожанином». Он входит в «дом бытия» (язык) местоимением «я». «Я» гарантирует место в языке. «Я» - это не знакдубликат имени, а нечто типа «абонемента», «входного билета», «должности». Человек-в-языке всегда «на долж- ности» (говорящего). Человека-в-языке видно насквозь, потому что он говорит, кажет себя, сказывается, являясь тем самым зрелищем. Человек и «про себя» мыслит языком, оставаясь зрелищем, иногда посмешищем для тех, кто видит его в тайных помыслах. По-настоящему религиозные люди, особенно из монахов, знают это и следят за чистотой мыслей, помыслов, желаний.

Человек во всех разговорных языках всегда не свободен и всегда под взглядом, порой недобрым. Гениальность человека начинается с того, что своим языком для него лично оказывается не родной язык, а тот сущий язык, на котором вещи видят друг друга и, соответственно, видят того, кто видит их. Если человек остается только в человеческом языке - агрессивном по отношению к вещам, то не стоит удивляться тому, что говорящий человек становится несимпатичным всему окружению, и вещи перестают говорить с ним, казать себя. В результате к композитору не приходят чарующие мелодии, к поэту не приходят благозвучные строфы, писатель остается без чувства языка, полководец остается без победоносных планов, а к женщине не приходит суженый. «Сущий язык» в философии озадачивает многих: так было, например, с творчеством Аристотеля или Гегеля, по поводу языка которых прозвучало немало проклятий. АльФараби жаловался на то, что «Категории» Аристотеля перечитал сорок раз, причем, без толку. Гегелевский стиль изложения У. Джеймс называл «бормотанием визионера», Л. Фейербах - «пьяными спекуляциями», А. Шопенгауэр объявлял «шарлатанством». Между тем, Аристотель с Гегелем говорили на одном языке - языке сущей феноменологии, в отличие, например, от Э. Гуссерля с его «строгой наукой» при игре в философию.

Тезис о том, что «язык - средство общения», затемняет другую сторону языка - как средства разобщения. Способность разобщения людей заложена в вербальном языке изначально. Ф. де Соссюр утверждал, что язык невозможно сохранить в неизменном виде, он постоянно изменяется во времени и пространстве. Можно сказать больше: язык живет своей жизнью на теле человечества, так что человечеству остается только роль технического обслуживания. В результате два соседних народа, обслуживая свои языки, перестают понимать друг друга. Т. Гоббс уподоблял государство огромному и чудовищному левиафану, то же можно сказать о языке. Человечество приручает языки, благодаря чему появляется возможность их пользования, но от этого языки не перестают быть «вещью-в-себе» в своей дикой свободе.

Сама сложность вербального языка, его структурного строения, свидетельствует отнюдь не в пользу тезиса «язык - средство общения». Довольно странным выглядит тот факт, что чем древнее язык, тем сложнее он организован. Как отмечает Т.Я. Елизаренкова, «для морфологии языка Ригведы характерна невероятно раз- 
вращенная флексия. У имени насчитываются десятки флексий, у глагола сотни. Существует сложная система противопоставления серий окончаний друг другу...» [Елизаренкова 1989, 509].

Повседневное общение людей, тем более в рамках семьи, племени, рода, совершенно не требует тщательного согласования слов в роде, числе, падеже, лице, времени, залоге; не требуется четкой артикуляции фонем. В живом общении люди понимают друг друга при всех дефектах дикции, телеграфном стиле речи, отсутствии словарного запаса, заикании и даже горячечном бреде. Вербальный язык избыточен для человечества в той же мере, в какой избыточным является либидо для сохранения рода. Родной язык и либидо многократно превышают необходимые и достаточные условия общения человечества в интересах сохранения жизни и ведения хозяйства. Тогда возникает философский вопрос: к чему такая избыточность и где искать её истоки?

В своё время 3. Фрейд доказал несоразмерность сексуального влечения человека его возрасту и возможностям, а российский этнограф академик Л.Я. Штернберг при исследовании шаманизма выявил нечеловеческое начало человеческой сексуальности. В так называемой «шаманской болезни» (период полового созревания) возникает тотально-сексуальная проблематика сновидений, по своим картинам соответствующая образам «Кама-Сутры», но не традициям своей семьи и племени. Подросток оказывается задавленным сновиденческими образами чуждой ему сексуальной практики, - как оказывается, ради того, чтобы заключить брачный завет со сновиденческим персонажем под именем «духа предков». «Дух предков» выбирает себе из всей молодежи будущего сексуального партнера для «священного брака» (иерогамии), эротическими сновидениями лишая подростка здорового сна и тем самым общения со сверстниками (в том числе эротического). Сексуальное избранничество в шаманизме, оборотной стороной которого выступают традиции девственности, приводит к тому, что шаман в иерогамии оказывается наложником (наложницей) сновиденческого персонажа, причем с реальным знанием изощренных сексуальных практик. Как пишет Л.Я. Штерберг, «не шаман избирает духа-покровителя, а дух избирает шамана» [Штернберг 1936, 41]. «Здесь, - продолжает этнограф, - с необычайной яркостью раскрываются совершенно своеобразные интимные отношения между шаманом и избравшим его духом, отношения, основанные на сексуальных эмоциях» [Штернберг 1936, 143]

Изощренность строения вербальных языков (в грамматике, морфологии, фонетике) при сопоставлении с историей шаманизма не может не наводить на мысль о том, что человек в языковом отношении точно так же является пленником некоего «духа предков», сонма ду- хов. Другими словами, надо иметь в виду, что язык, как и сексуальность человека, своими корнями может уходить в шаманизм, а отнюдь не в семиотику и социологию. С этой точки зрения можно говорить о парадоксе языка: родной язык устроен таким образом, как будто он не предназначен родным людям. Сложность структуры вербального языка объясняется тем, что реальное общение людей, на виду друг у друга, оказывается полностью проигнорированным. Соответственно, назначение вербального языка состоит в чем-то другом, не в общении в кругу соплеменников. Если исходить из того факта, что язык и знание в чем-то тождественны, а изначальные знания имели рецептурный характер, то придется признать связь языка с проблемой рецептурного знания. В мифологии народов мира не случайно выделяется особый вид мифов, связанных с «культурным героем», который научает человека огню, приручению животных, ткачеству, мореходству и всему множеству видов хозяйствования. Культурный герой в эпоху шаманизма «действовал» посредством либо сна, либо транса. Рецептурное знание возникало как видение в трансовом состоянии сознания, но реализуемо оно было при переходе к бодрствующему сознанию, в связи с чем и возникает необходимость кодификации видения при переводе в телесную реальность, например, в форме жестов. Жест - это мышечная кодификация видения, которая с точки зрения межличностного общения принимает характер мимики, пантомимы, голоса. Фонетический язык «подсажен» на мышечные реакции взгляда, рук и ног, движение крови; он, собственно, и выполняет функцию их координации при транспонировании видения в поведение. В так называемой «экспрессивной фразеологии» слов минимум, но мышечных реакций максимум. Развитие речи, как известно, пошло в противоположном направлении.

Источник «рецептурного знания» вне опыта человечества, вне логики или «подсознания»; рецептурное знание является внеопытным, внеразумным, нечеловеческим, но истинным в конкретных условиях той или иной «проблемной ситуации». Исторически «проблема» тесно связана с «мольбой», с призывом о помощи. Естественно, что просьба о помощи должна быть корректно сформулированной, иначе можно получить то, чего никто не хотел. Диалог с трансцендентной реальностью в условиях возможности быть неправильно понятым привел к изощренной казуистике структуры «родного языка». Родной язык не предназначался родным людям; он предназначался для диалога с персонажами трансцендентной реальности «вне прямой видимости» (как говорят летчики). Общение «вне видимости» достигается за счет развития технических средств, роль которых и взял на себя «родной язык» с его избыточной оснащенностью в фонетике, морфологии и синтаксисе. Страстные моления с боязнью не быть понятым привели к ритми- 
зации речи, к многочисленным повторам, что и нашло свое обозначение под видом поэзии. Трудно не увидеть поэзию в таком, например, «заговоре» от неизвестной болезни (шепотом):

«Стань ты, Пречиста, з помощами, а я со словами:

Вид твоих очей, вид твоих плечей,

Вид белого тела, вид желтых костей,

Вид червонной крови, вид щирого сердиа.

Tут тоби не стояти, билого тела не пусвати,

Червонной крови не питии, жовтой кости не ломати. Иди себе на очерета, на болота,

Де солнце не сяе, де месяц не свите, де люды не ходют» [Ветухов 1907, 102].

Вот еще пример заговора (от зубной боли):

«Заря зорюшка, заря вечерняя!

Как ты утихаешся, как ты улегаешся,

Пускай у (такой-то) зуб желанный утихается, улегается,

С буйной головы, с ясных очей, с черных бровей,

С ретивого сердиа, сжил, поджил, с состав, сполустав.

Зубище, зубище, иди ты на дубище...»

[Ветухов 1907, 102].

Заговор совершенно не обязательно произносить артикулировано, с соблюдением интонации и динамических оттенков. В заговоре важен повтор, настойчивое донесение смысла путем многократного возвращения к одному и тому же, так что рифма является не более чем подтверждением ритма. В заговоре мысль кружится вокруг одной оси, как бы зазывая покружиться вместе. Задача заговора состоит в том, чтобы создать место встречи, обставить это место декорациями и принять в дом званного гостя-покровителя. Слова в заговоре не есть, собственно, слова и предложения; скорее, слова в заговоре есть «мыслеформы» теософии Р. Штайнера, они суть видимые онтосы. «Речь, - писал Д.Н. Овсянико-Куликовский, - можно было - по понятиям древности - видеть, ибо «видеть» и «слышать» были не то, чтобы совсем синонимы, но понятия весьма близкие...сливающиеся в одном основном представлении текущей жидкости...» [Овсянико-Куликовский 1883, 69]. В гимне богине Речи Овсянико-Куликовский находит прямое подтверждение своей мысли:

«...Мною вкушает пищу тот, кто видит, кто дышит, кто слышит сказанное,-

(сами того не зная), они при мне состоят («они Омне живут!»).

Слушай! Слушайся! Я говорю правду»

[Овсянико-Куликовский 1883, 118].

Признание сакральности языка имеет важное для философии следствие: философия религии должна предшествовать философии языка и быть не сравнительным религиоведением, а онтологией персонажей, известных по трансовому опыту. По своему происхождению язык связан с трансовым опытом человечества, через который и проходит, я утверждаю, «путь к языку». Насколько оригинальна эта идея? Во всяком случае, она не настолько нова, чтобы приписывать авторство себе. Еще Ф.де Соссюр, страстный сторонник знаковости языка, иронизировал над «ясновидением»: «Некоторые ясновидцы заявляют: «Язык есть нечто, находящееся совершенно вне человека и имеющее собственную организацию, это некая паразитарная растительность, распространившаяся по поверхности рода человеческого». Другие говорят: «Язык есть нечто человеческое, но он подобен естественным функциям»» [Соссюр 1990, 93]. Для М. Хайдеггера, избравшего для языка путь через поэзию, а не через знаки, ирония Ф. де Соссюра была бы совершенно неуместной. Поэзии немецкий философ придает трансцендентальное значение, обыгрывая упоминание «богов» в литературе романтизма: «...боги сами приводят нас к языку. Как говорят боги? ...намеки - Bот с незапамятных времен язык богов... Сказывание поэта есть улавливание этих намеков...» [Хайдеггер 2003, 91]. Как осуществляется это самое «улавливание»? - Усилиями с двух сторон: «Но боги только тогда могут войти в слово, - уточняет М. Хайдеггер, - когда они сами спрашивают нас и спрашивают с нас» [Хайдеггер 2003, 79]. Можно понять лингвистов, которые отказываются понимать соображения о том, как боги «могут войти в слово». Лингвисты понимают язык через семиотику-для-нас, в то время как возможна семиотика-для-богов, в которой могут быть иные измерения языка, иные виды «значений». Например, боги входят не в слово, а в аромат слова, в аромат фразы или в музыку слова, в музыку имени (любимой женщины, родины); в пространствах музыки или аромата места предостаточно.

В лингвистике нет богов, но тогда нет и того диалога, который предшествует языку и делает его возможным. Для М. Хайдеггера принцип языка ясен однозначно: язык возникает на границе двух реальностей, и возникает он как диалог людей и богов, причем на общей им территории «дома бытия». Чтобы начать говорить, надо войти в язык. Богам тоже надо «войти в слово», но для этого слово должно сопрягаться в своих частях, образуя непрерывность при любой длине этого слова-речи. Неправильная речь не мешает людям двигаться в ней, но является серьёзным препятствием для богов: они её просто покидают (так люди покидают транспортные средства, увязшие в дорожной грязи). При правильной речи (сработанной поэтами) боги не только входят в слово, но они плывут в речи по её течению, имея возможность этим течением управлять. Так возникает «соработничество» людей и богов, - «синергия», которую мы называем «языком», а наблюдаем в «речи».

Верил ли М. Хайдеггер в теистичную теорию языка, развертываемую им на материале авторской поэзии (минуя этнографию)? Скорее всего, нет, иначе не называл бы путь к языку «длиннейшим из всех». Хайдеггер «вычис- 
лял» богов подобно тому, как его современник Луи де Бройль вычислял свои «волны». Хайдеггеровские «боги» исключительно математичны, от чего на «пути к языку» возникает серьёзное препятствие - онтология не языка, а самих богов. Препятствие было непреодолимым, в чем отдавал себе отчет М. Хайдеггер, полагая для себя достаточным вывести язык за пределы лингвистики и лично сокрывшись в поэзии. Не случайно на вопрос корреспондента (в 1969 году): «Говорят, что есть две темы, по поводу которых Вы отказываетесь отвечать: то, над чем Вы работаете и проблема Бога», - Хайдеггер ответил в очередной раз уклончиво: «Я предпочитаю, чтобы читали мои сочинения» [Хайдеггер 1991, 158]. В философии М. Хайдеггера боги по его воле должны оставаться всего лишь «интенциями», между тем как табуирование темы «онтология богов» не может продолжаться до бесконечности, и «вопрос о языке» лишний раз свидетельствует об этом.

1. Бердяев Н.А. Смысл истории. М.,1990.

2. Ветухов А. Заговоры, заклинания, обереги и другие виды народного врачевания. Вып.1-2. Варшава, 1907.

3. Гумбольдт В. Язык и философия культуры. М., 1985.

4. Елизаренкова Т.Я. «Ригведа» - великое начало индийской литературы и культуры.ІІ Ригведа. Мандалы 1-4. М.: Наука. 1989.

5. Овсянико-Куликовский Д.Н. Опыт изучения вакхических культов индоевропейской древности в связи с ролью экстаза на ранних ступенях развития общественности. Ч.1. Одесса, 1883.

6. Мерло-Понти М. Знаки. М.,2001.

7. Мерло-Понти М. Око и дух. М., 1992.

8. Мечковская Н.В. Язык и религия. Минск, 1998.

9. Соссюр Ф. де. Заметки по общей лингвистике. М., 1990.

10. Цицерон М. Избранные сочинения. М., 1975.

11. Хайдеггер М. Разъяснения к поэзии Гёльдерлина. СПб, 2003.

12. Хайдеггер М. Разговор на проселочной дороге. М., 1991

13. Хайдеггер М. Время и бытие. Статьи и выступления. М.,1993.

14. Штернберг Л.Я. Первобытная религия в свете этнографии. Л.,1936.

(с) Костецкий Виктор Валентинович (kostavictor@yandex.ru).

Журнал «Современная наука: актуальные проблемы теории и практики»

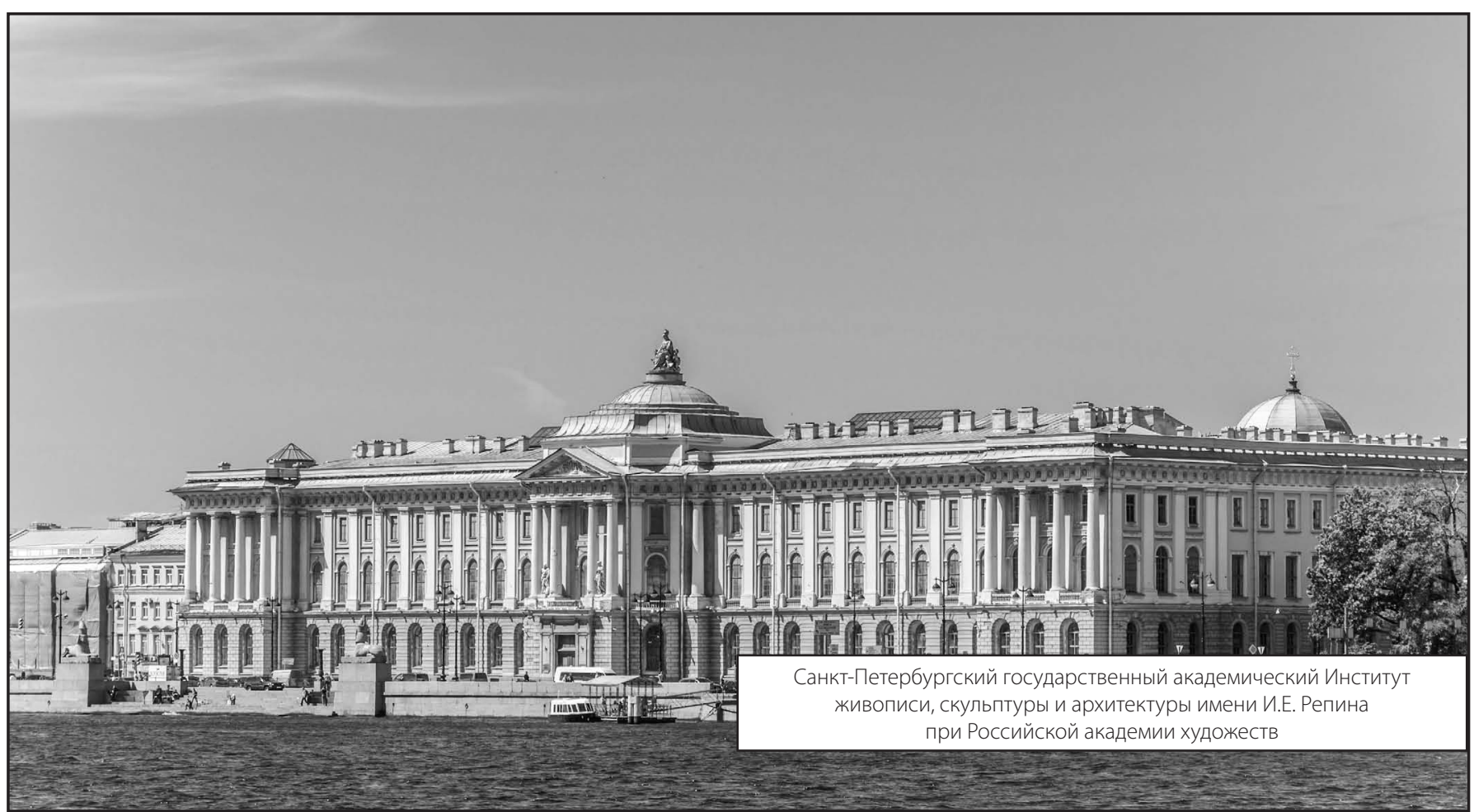

